UDK: 371.135/136; 371.213

Prethodno saopštenje

Primljeno: 16.4.2018.

Revidirana verzija: 22.6.2018.

Odobreno za štampu: 25.6.2018.

\title{
NASTAVNIK - GLAVNI FAKTOR UVOĐENJA NAŠE ŠKOLE U PEDAGOŠKI MILJE SAVREMENE EVROPE I SVETA
}

\author{
Ilinka Mušikić Popović1 \\ Univerzitet u Prištini s privremenim sedištem u Kosovskoj Mitrovici, Filozofski \\ fakultet, Katedra za pedagogiju
}

\begin{abstract}
Apstrakt: U radu se razmatra uloga nastavnika kao najbitnijeg nosioca pedagoškog rada škole, njene organizacije, toka nastavnog procesa, vaspitnog delovanja na učenike i predstavljanja škole prema društvenoj sredini (Vidi: S. Kačapor, 2005: 209-211). Nastavnik je prikazan kao najbitniji faktor svih promena u školi, pa time i kao najbitniji faktor preko koga se naša škola može modernizovati, prihvatiti izazove iz moderne Evrope i sveta, te faktor koji će našu školu konačno uvrstiti u red modernih škola ravnopravnih sa školama najrazvijenijih zemalja Evrope i sveta.

U radu su jasno odvojena dva dela: (1) teorijski u kojem se razmatraju najbitnija pitanja savremene škole, kako ona koja je afirmišu kao uspešnu organizaciju, tako i ona koja daju povod za argumentovanu kritiku. Posebno mesto je dato nastavniku, njegovom liku, njegovoj funkciji, mestu, ulozi, pedagoškom taktu - nosiocu svih najbitnijih funkcija škole i stubnom faktoru njenog uspeha ili/i neuspeha; (2) empirijiski deo u kome je dat samo izvod iz obimnijeg istraživanja koji se eksplicitno odnosi na samo jednu pedagošku pojavu - pedagoški takt nastavnika.
\end{abstract}

Ključne reči: pedagogija, vaspitanje, obrazovanje, nastavnik, škola, školska organizacija.

\section{Uvod}

Škola je uistinu najstabilnija društvena institucija. Pa ipak u njenom radu se mogu osetiti brojne slabosti koje daju povod za argumentovanu kritiku. Tragajući za argumentima društvene i pedagoške opravdanosti kritike savremene škole u Republici Srbiji, oslonili smo se na najbitnija dokumenta koja predstavljaju podlogu za bitnije reformske zahvate. Pre svega to su:

- Zakon o osnovnoj školi (,Službeni glasnik RS“, br. 50/92, 53/93, 67/93, 48/94 i 66/94),

\footnotetext{
${ }^{1}$ linamusikic@gmail.com
} 
- Strategija razvoja obrazovanja u Srbiji do 2020. godine (,Službeni glasnik RS“, br. 107/2012),

Podaci Unije sindikata prosvetnih radnika Srbije (http://www.unijasprs.org.rs/),

Podaci do kojih je došao Odbor za obrazovanje SANU,

Pravilnik o standardima kvaliteta rada ustanove („Službeni glasnik RS“, broj 7/2011 i 68/2012), kao i razni drugi pravilnici kojima se rešavaju brojna pitanja unutrašnje organizacije i rada škole, Evropi.

Brojni međunarodni akti koji se bave organizacijom rada škole u Savremenoj

Reformisanje sistema vaspitanja i obrazovanja u Srbiji mora se sagledavati u kontekstu ukupnih društvenih kretanja u Evropi i svetu u celini. U obrazovnom sistemu Republike Srbije već se uveliko preduzimaju brojni krupni koraci postizanja ciljeva koji su iskazani u međunarodnim dokumentima.

Savremena osnovna škola je u direktnoj zavisnosti od društvenog i ekonomskog razvoja u Republici Srbiji i opredeljenja za integraciju u Evropsku zajednicu. Zapravo, prema (Danilović, 2011: 33) Evropa želi da:

- međusobno približi (ujedini, poveže) svoje narode u moćnu ujedinjenu Evropu, tj. Evropsku zajednicu naroda;

- poveća njihovo uzajamno, međusobno razumevanje, saradnju i poštovanje;

- pojača njihove međusobne veze i odnose na svim poljima (ekonomskim, kulturnim, političkim, naučnim, medicinskim, ekološkim, tehnološkim, proizvodnim itd.);

- smanji međusobne tenzije, moguće sukobe, ratne opcije i rešenja;

- poveća poštovanje ljudskih prava, demokratskih vrednosti, pravnih normi, obaveza, pravosudnih odluka itd.;

- omogući lakše dogovaranje i pronalaženje zajedničkih interesa na ekonomskom, političkom, ekološkom, kulturnom itd. planu;

- sačuva kulturu, kulturne običaje, tradiciju, istoriju pa i različitosti njenih članica;

- međusobno integriše ljude različitih tradicija, običaja, političkih uverenja, nacija, religija, jezika itd.;

- decentralizuje i demokratizuje sisteme obrazovanja svojih članica;

- razvije „evropske dimenzije“ obrazovanja, tj. ,evropski identitet“.

Budući razvoj Republike Srbije i Evrope predstavlja kontekst u kome će se dalje razvijati osnovna škola.

Do 2020. godine svi dečaci i devojčice zakonom predviđenog školskog uzrasta (minimalno 98\% generacije), bez obzira na socioekonomske, zdravstvene, regionalne, nacionalne, jezičke, etničke, verske i druge karakteristike, obuhvaćeni su kvalitetnim osnovnim obrazovanjem i vaspitanjem iz kojeg osipanje nije veće od 5\% ( $\mathrm{tj}$. završava osnovnu školu 93\% generacije), ne samo na nacionalnom nivou već i za kategorije dece iz osetljivih grupa (seoska, romska, siromašna deca i deca sa invaliditetom i smetnjama u razvoju) (Strategija razvoja obrazovanja u Srbiji do 2020. godine, „Službeni glasnik RS“, br. 107/2012.). 
Savremena škola se suočava sa krupnim promenama uslovljenim brzim razvojem nauke tehnike i tehnologije, koje nose nužne socijalne i ekonomske promene, ali i promene političkog sistema i novog odmeravanja snaga u svetu. Sticanje materijalnih dobara i razvoj kapitala, postale su vrednosti koje se stavljaju ispred društvenih, pa i ispred duhovnih vrednosti. Uvođenje automatizovanih mašina u proces proizvodnje označio je novu etapu u razvoju ljudske civilizacije (Kulić, 1996). To nužno dovodi do strahovite pohlepe za sticanjem: profit i zarada mera su svega, rada, ugleda, životnog standarda; i ne treba se, onda, čuditi što ljudi svu ambiciju usmeravaju na to da zarade što više novca, što su mase naprosto opijene numerički odštampanom hartijom (Kulić, 1996). Škola u tim, novonastalim društvenim okolnostima, traži put do jasnijih ciljeva procesa vaspitanja i obrazovanja: posle zdravog, informatičkog, otvorenog, obrazovanog društva dominantna vizija i ideal postaje društvo koje uči (Kulić i Despotović, 2010). To podrazumeva da je osnovna škola samo jedan deo sistema obrazovanja, a da je savremeno društvo koncipirano na doživotnom (permanentnom) obrazovanju i učenju. Otuda naše društvo dobija novi, savremeni, epitet: „Društvo koje uči“, odnosno „društvo znanja“. Zato savremenu osnovnu školu moramo posmatrati kao instituciju sistema vaspitanja i obrazovanja koja doživljava modernizaciju i transformaciju, jer je to pretpostavka celokupnog društveno-ekonomskog razvoja Srbije.

Svetski eksperti za vaspitanje i obrazovanje ukazuju na glavne karakteristike, probleme i protivurečnosti koje se moraju imati u vidu u projekcijama ciljeva, sistema, sadržaja, organizacije i tehnologije ostvarivanja vaspitno-obrazovne delatnosti u 21. veku. To su u prvom redu: globalizacija sveta (stvaranje jedinstvenog ekonomskog, političkog i kulturnog prostora sa brojnim protivrečnostima); sve brži transfer znanja i tehnologija; porast uloge znanja kao razvojnog resursa; univerzalizacija znanja, vrednosti i obrazovanja; težnja ka ostvarivanju demokratskih ideala društva i njegovoj humanizaciji, i neprekidne promene, pronalasci i napredak u nauci, tehnici, tehnologiji i proizvodnji (Ilić i dr., 2012).

Nema školskog sistema u Evropi koji u proteklim godinama nije prošao različite reforme kurikuluma, strategija, formacije nastavnika i sl. (http://europa/eu/ int/; www.eurydice.int). Mnoge su promene uslovljene potrebom da se udovolji različitim društvenim, kulturnim i profesionalnim zahtevima. Istovremeno, zahvaljujući procesu političkog ujedinjavanja kontinenta, svuda se uočava trajni napor oko prilagođavanja nacionalnih školskih sistema parametrima definisanim od strane Evropske unije i delovanja drugih međunarodnih ustanova (kao što je Veće Evrope, UNESCO, OEBS). Svi ti činioci doprinose redefinisanju ciljeva školskoga vaspitnoobrazovnog delovanja i reorganizaciji samih načina/modela poučavanja/učenja.

Kada su u pitanju promene vaspitanja i obrazovanja u školskom sistemu u Srbiji ponovo ističemo Strategiju razvoja obrazovanja koja je izrađena kao osnova za promene u programiranju i načinu rada u osnovnom školstvu (,Službeni glasnik RS“, br. 107/2012.).

Cilj ovih istraživanja je bio da se utvrdi da li je organizacija rada osnovne škole zasnovana na savremenim dostignućima pedagoške nauke, kao i da li je u koncipiranju budućnosti naše osnovne škole, u skladu sa razvojnim putem Republike Srbije, 
potrebno pojačano i dodatno obučavati nastavnike kako bi naša škola mogla držati korak sa osnovnim školama u razvijenoj Evropi i svetu.

U ovom radu želimo prikazati samo deo rezultata jednog istraživačkog zadatka koji je glasio: „Ispitati stavove ispitanika o nekim aspektima pedagoškog takta nastavnika.“

\section{Metod}

U periodu 2014/15. godine izvršili smo obimno pedagoško istraživanje problema pedagoške zasnovanosti rada savremene osnovne škole. Ispitivali smo procene ispitanika (učenika i nastavnika) o tome na kojim pedagoškim osnovama se zasniva organizacija rada osnovne škole, odnosno koje su to pedagoške osnove na kojima treba zasnovati osnovnu školu Republike Srbije u budućnosti.

Postavili smo više istraživačkih zadataka, više nezavisnih i zavisnih varijabli i u realizaciji postavljnih zadataka jasno definisali polazne predpostavke - hipoteze.

U realizaciji ovog zadatka postavili smo hipotezu: "Pedagoški takt nastavnika varira u zavisnosti od stručne spreme, godina radnog staža i pola nastavnika“.

Istraživanje smo zamislili kao operativno (primenjeno) istraživanje, u kome smo se koristili različitim istraživačkim metodama (metodu teorijske analize, deskriptivnu metodu, kauzalnu metodu i Sarvey metod). Isto tako koristili smo i raznovrsne tehnike (anketiranje, skaliranje, testiranje, intervjuisanje, sistematsko neeksperimentalno posmatranje grupa i pisanje stavova u vidu eseja).

Populaciju istraživanja je predstavljala Zajednica srpskih opština na Severu Kosova i Metohije. U cilju obezbeđivanja mogućnosti komparativnog posmatranja sa stanjem na ostalim delovima Srbije, obuhvaćena je i jedna osnovna škola u Nišu. Uzorkom je obuhvaćen sledeći broj ispitanika:

- iz populacije direktora i stručnih saradnika $=20$ ispitanika,

- iz populacije učenika $=736$ ispitanika,

- iz populacije nastavnika $=136$ ispitanika.

Zbog prirode i posebno obima ovog rada nisu prikazani svi detalji o strukturi populacije i uzorka u pogledu nezavisnih varijabli.

Da bi testirali postavljenu hipotezu (da pedagoški takt nastavnika varira u zavisnosti od stručne spreme, godina radnog staža i pola nastavnika), ispitivali smo stavove direktora, stručnih saradnika i nastavnika.

Pedagoška pojava „neki pokazatelji pedagoškog takta nastavnika“ imala je status zavisne varijable, dok su status nezavisnih varijabli imale pojave: naziv škole, školska sprema ispitanika, zanimanje (status u školi), broj godina radnog staža i pol.

Mišljenja i stavove direktora i stručnih saradnika ispitivali smo u neposrednom razgovoru na osnovu protokola intervjua, kao i u predhodnom istraživačkom zadatku. Direktorima i stručnim saradnicima je u pismu, odnosno protokolu intervjua, unapred dostavljen spisak pitanja o kojima će se voditi razgovori.

Da bi eksplicitno došli do procena nekih pokazatelja pedagoškog takta nastavnika, kao i da bismo mogli te procene uporedno da posmatramo, u protokolu intervjua smo, za direktore i stručne saradnike, postavili i sledeća pitanja: 
- da je tzv. ,živa reč nastavnika” preovlađujući izvor za sticanje znanja,

- koliko nastavnici istrajavaju u tome da učenici nauče da samostalno obrazlažu to kako su došli do rešenja,

- koliko su nastavnici vešti u upravljanju učenjem na času,

- da li nastavnici pravilno i efikasno koriste vremena na nastavnim časovima,

- koliko nastavnici postižu radnu disciplinu na nastavnim časovima,

- koliko nastavnici koriste raznovrsna nastavna sredstava na nastavnim časovima,

- ocenjuju li nastavnici u skladu sa Pravilnikom o ocenjivanju učenika,

- da li nastavnici uče učenike kako da oni sami ocenjuju svoja znanja, rad i postignuća,

- koliko nastavnici poštuju svoje učenike i

- koliko nastavnici daju mogućnost učenicima da postavljaju pitanja, diskutuju i komentarišu u vezi sa predmetom učenja na času.

\section{Rezultati istraživanja}

Direktori osnovnih škola procenjuju da je nastava znatno modernizovana. Međutim, još uvek je tzv. ,živa reč nastavnika” glavni izvor znanja na nastavnim časovima. Nastavnici su nezamenjiv faktor u procesu sticanja znanja u nastavi. Ma koliko delovalo da je to vraćanje na klasičnu školu i nastavu, direktori smatraju da samo treba jačati takvu ulogu nastavnika.

Stručni saradnici, posebno pedagozi, imaju nešto drugačije stavove. Oni smatraju da treba prevazići ,predavačku nastavu“, a zameniti je novim didaktičkim sistemima; odnosno ističu potrebu i mogućnost programirane nastave i autodidaktičkog rada učenika.

Stavovi direktora i stručnih saradnika, po svim navedenim pitanjima se razlikuju utoliko što direktori više potenciraju afirmativne odgovore u kojima se favorizuje uspeh, dok stručni saradnici iskazuju potrebu stalnog unapređivanja i modernizacije rada škole u svim oblastima.

U narednom delu našeg rada mi smo tabelarno i grafički prikazali stavove procene nastavnika (s obzirom na pol, školsku spremu, zanimanje, broj godina radnog staža, i školu u kojoj predaju) o nekim pokazateljima pedagoškog takta nastavnika. Nastavnici su se izjasnili na osnovu tvrdnji prikazanih u tabeli 1 . 
Tabela 1. Stavovi nastavnika o nekim pokazateljima pedagoškog takta nastavnika

\begin{tabular}{|c|c|c|c|c|c|c|}
\hline \multirow{2}{*}{$\begin{array}{l}\text { Red. } \\
\text { br. }\end{array}$} & \multirow{2}{*}{$\begin{array}{l}\text { Tvrdnje o resursima u funkciji kvaliteta } \\
\text { rada škole }\end{array}$} & \multicolumn{5}{|c|}{ STEPENI PROCENE } \\
\hline & & $\begin{array}{l}\text { Odličan } \\
\text { (5) }\end{array}$ & $\begin{array}{l}\text { Vrlodobar } \\
\quad(4)\end{array}$ & $\begin{array}{l}\text { Dobar } \\
\text { (3) }\end{array}$ & $\begin{array}{l}\text { Dovoljan } \\
\text { (2) }\end{array}$ & $\begin{array}{l}\text { Nedovoljan } \\
\text { (1) }\end{array}$ \\
\hline 1. & $\begin{array}{l}\text { Korišćenje od strane učenika, pored } \\
\text { "žive reči nastavnika " i raznih drugih } \\
\text { izvora za sticanje znanja }\end{array}$ & $\begin{array}{c}62 \\
45,6 \%\end{array}$ & $\begin{array}{c}53 \\
39,0 \%\end{array}$ & $\begin{array}{c}20 \\
14,7 \%\end{array}$ & $\begin{array}{c}1 \\
0,7 \%\end{array}$ & $\begin{array}{l}0 \\
0\end{array}$ \\
\hline 2. & $\begin{array}{l}\text { Umešnost učenika u obrazlaganju toga } \\
\text { kako su došli do tačnih rešenja }\end{array}$ & $\begin{array}{c}44 \\
32,4 \%\end{array}$ & $\begin{array}{c}66 \\
48,5 \%\end{array}$ & $\begin{array}{c}25 \\
18,4 \%\end{array}$ & $\begin{array}{c}1 \\
0,7 \%\end{array}$ & $\begin{array}{l}0 \\
0\end{array}$ \\
\hline 3. & Moja veština upravljanja učenjem na času & $\begin{array}{c}93 \\
68,4 \%\end{array}$ & $\begin{array}{c}40 \\
29,4 \%\end{array}$ & $\begin{array}{c}3 \\
2,2 \%\end{array}$ & $\begin{array}{l}0 \\
0\end{array}$ & $\begin{array}{l}0 \\
0\end{array}$ \\
\hline 4. & $\begin{array}{l}\text { Pravilnost i efikasnost korišćenja } \\
\text { vremena na nastavnim časovima }\end{array}$ & $\begin{array}{c}88 \\
64,7 \%\end{array}$ & $\begin{array}{c}44 \\
32,4 \%\end{array}$ & $\begin{array}{c}4 \\
2,9 \%\end{array}$ & $\begin{array}{l}0 \\
0\end{array}$ & $\begin{array}{l}0 \\
0\end{array}$ \\
\hline 5. & $\begin{array}{l}\text { Radna disciplina na mojim nastavnim } \\
\text { časovima }\end{array}$ & $\begin{array}{c}97 \\
71,3 \%\end{array}$ & $\begin{array}{c}34 \\
25,0 \%\end{array}$ & $\begin{array}{l}5 \\
3,7 \%\end{array}$ & $\begin{array}{l}0 \\
0\end{array}$ & $\begin{array}{l}0 \\
0\end{array}$ \\
\hline 6. & $\begin{array}{l}\text { Korišćenje raznovrsnih nastavnih } \\
\text { sredstava na mojim nastavnim časovima }\end{array}$ & $\begin{array}{c}84 \\
61,8 \%\end{array}$ & $\begin{array}{c}40 \\
29,4 \%\end{array}$ & $\begin{array}{c}12 \\
8,8 \%\end{array}$ & $\begin{array}{l}0 \\
0\end{array}$ & $\begin{array}{l}0 \\
0\end{array}$ \\
\hline 7. & $\begin{array}{l}\text { Ocenjivanje u skladu sa Pravilnikom o } \\
\text { ocenjivanju učenika }\end{array}$ & $\begin{array}{c}113 \\
83,1 \%\end{array}$ & $\begin{array}{c}22 \\
16,2 \%\end{array}$ & $\begin{array}{c}1 \\
0,7 \%\end{array}$ & $\begin{array}{l}0 \\
0\end{array}$ & $\begin{array}{l}0 \\
0\end{array}$ \\
\hline 8. & $\begin{array}{l}\text { Učenje učenika kako da sami ocenjuju } \\
\text { svoja znanja, rad i postignuća }\end{array}$ & $\begin{array}{c}86 \\
63,2 \%\end{array}$ & $\begin{array}{c}44 \\
32,4 \%\end{array}$ & $\begin{array}{c}5 \\
3,7 \%\end{array}$ & $\begin{array}{c}1 \\
0,7 \%\end{array}$ & $\begin{array}{l}0 \\
0\end{array}$ \\
\hline 9. & Koliko ja poštujem učenike & $\begin{array}{c}132 \\
97,1 \%\end{array}$ & $\begin{array}{c}4 \\
2,9 \%\end{array}$ & $\begin{array}{l}0 \\
0\end{array}$ & $\begin{array}{l}0 \\
0\end{array}$ & $\begin{array}{l}0 \\
0\end{array}$ \\
\hline 10. & $\begin{array}{l}\text { Koliko dajem mogućnost učenicima da } \\
\text { postavljaju pitanja, diskutuju i komentarišu } \\
\text { u vezi sa predmetom učenja na času }\end{array}$ & $90,4 \%$ & $9,6 \%$ & 0 & 0 & 0 \\
\hline
\end{tabular}

Analizirajući dobijene rezultate kroz frekvencije procena nastavnika, možemo zaključiti da je najviše nastavnika iskazalo ocenu „odličan (5)” za indikator „,koliko ja poštujem učenike”, njih 97,1\%. Ocenu ,vrlodobar (4)” najviše nastavnika je iskazalo za tvrdnju „umešnost učenika u obrazovanju toga kako su došli do tačnih rešenja” - 32,4\%. Ocenu „dobar (3)" najviše nastavnika je iskazalo na prethodno navedeni indikator, tj. indikator pod rednim brojem $2-18,4 \%$. Konačno, ocenu „dovoljan (2)”, po jedan nastavnik se iskazao za tvrdnje „korišćenje od strane učenika, pored 'žive reči' nastavnika i raznih drugih izvora za sticanje znanja”, „umešnost učenika u obrazovanju toga kako su došli do tačnih rešenja” i ,učenje učenika kako da sami ocenjuju svoja znanja, rad i postignuća”. Ocenu „nedovoljan (1)” nijedan nastavnik nije odabrao da iskaže svoje slaganje, odnosno neslaganje sa ponuđenim indikatorima, što smo i prikazali u tabeli broj 1 .

U nastavku smo prikazali dobijene rezultate iskazene kroz neke statističke postupke. 
Tabela 2. $\chi^{2}$ za indikatore procene nastavnika o nekim aspektima pedagoškog takta nastavnika

\begin{tabular}{|c|c|c|}
\hline Red. br. & Indikator & $\chi^{2}$ \\
\hline 1. & $\begin{array}{l}\text { Korišćenje od strane učenika, pored "žive reči nastavnika" i raznih drugih izvora } \\
\text { za sticanje znanja }\end{array}$ & 71.471 \\
\hline 2. & Umešnost učenika u obrazlaganju toga kako su došli do tačnih rešenja & 67.471 \\
\hline 3. & Moja veština upravljanja učenjem na času & 90.279 \\
\hline 4. & Pravilnost i efikasnost korišćenja vremena na nastavnim časovima & 77.882 \\
\hline 5. & Radna disciplina na mojim nastavnim časovima & 97.603 \\
\hline 6. & Korišćenje raznovrsnih nastavnih sredstava na mojim nastavnim časovima & 58.118 \\
\hline 7. & Ocenjivanje u skladu sa Pravilnikom o ocenjivanju učenika & 156.368 \\
\hline 8. & Učenje učenika kako da sami ocenjuju svoja znanja, rad i postignuća & 139.235 \\
\hline 9. & Koliko ja poštujem učenike & 120.471 \\
\hline 10. & $\begin{array}{l}\text { Koliko dajem mogućnost učenicima da postavljaju pitanja, diskutuju i komentarišu } \\
\text { u vezi sa predmetom učenja na času }\end{array}$ & 88.971 \\
\hline
\end{tabular}

Na osnovu dobijenih rezultata $\chi^{2}$ testa (Tabela 2 ) možemo konstatovati da rezultati variraju u zavisnosti od indikatora od 58.118 („korišćenje raznovrsnih nastavnih sredstava na mojim nastavnim časovima“) sve do 156.368 („ocenjivanje u skladu sa Pravilnikom o ocenjivanju učenika"). Dobijena vrednost $\chi^{2}$ test za sve indikatore na nivou značajnosti od 0,01 prelazi graničnu vrednost $\chi^{2}$, što znači da je razlika između empirijskih i teorijskih frekfencija na ovom nivou statistički značajna.

Drugim rečima, ponuđene tvrdnje $u$ skalama procene, nisu jednako ocenjivane od strane nastavnika. To znači, da u neposrednom nastavnom radu, pedagoške pojave opisane kao „tvrdnje“ u skalama procene, nisu jednakomerno prihvaćene i prisutne. Sve pojave su iskazane kao nedovoljno zastupljene, s obzirom na vrednosti $\chi^{2}$ testa, a posebno sledeće pojave: „Ocenjivanje u skladu sa Pravilnikom o ocjenjivanju učenika“, „Učenje učenika kako da sami ocenjuju svoja znanja, rad i postignuća“ i „,Koliko ja poštujem učenike“.

Međutim, u skalama procene su vidljiva slaganja sa pozitivnim, čak afirmativnim stavovima o postavljenim tvrdnjama. To se vidi iz tabele 2 , kao iz grafikona 1 .

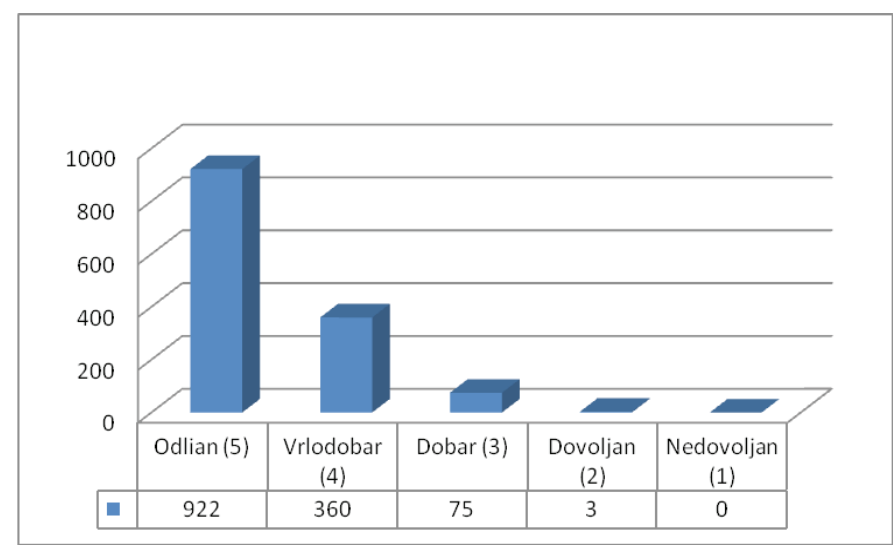

Grafikon 1. Stavovi nastavnika o nekim pokazateljima pedagoškog takta nastavnika 
Na osnovu procene nastavnika o datim indikatorima (Grafikon 1) dolazimo do zaključka da se najviše nastavnika izjasnilo za procenu ,odličan (5)", njih 67,79\%, zatim „vrlodobar (4)” 26,47\%. Nakon toga slede procene: „dobar” 5,51\%, „dovoljan” $0,22 \%$, dok se za procenu ,nedovoljan (1)" nije niko izjasnio.

Da li su razlike u procenama nastavnika o resursima u funkciji kvaliteta rada škole, statistički značajne izračunali smo putem $\chi^{2}$ testa.

Zbirne podatke uneli smo u tabelu 3.

Tabela 3. $\chi^{2}$ zbirna procena nastavnika o resursima u funkciji kvaliteta rada škole

\begin{tabular}{ccccc}
\hline Fo & $\mathrm{ft}$ & fo-ft & $(\mathrm{fo}-\mathrm{ft})^{2}$ & $(\mathrm{fo}-\mathrm{ft})^{2} / \mathrm{ft}$ \\
\hline 922 & 272 & 650 & 422500 & 1553,30 \\
360 & 272 & 88 & 7744 & 28,47 \\
75 & 272 & -197 & 38809 & 142,68 \\
3 & 272 & -269 & 72361 & 266,03 \\
0 & 272 & -272 & 73984 & 272 \\
& & & & $\chi^{22262,48}$ \\
\hline
\end{tabular}

Izračunata vrednost $\chi^{2}=2262,48$ na nivou značajnosti od $0,05 \%$ prelazi graničnu vrednost $\chi^{2}$, te zaključujemo da su odstupanja u proceni nastavnika o nekim pokazateljima pedagoškog takta nastavnika iskazana u empirijskim frekvencijama statistički značajna. Iz analize je vidljivo da među nastavnicima postoji velika razlika u proceni.

S obzirom da su uočene određene razlike u distribuciji odgovora, odlučili smo se da posmatramo procene kroz nezavisne varijable: pol nastavnika, zatim školsku spremu, zanimanje, broj godina radnog staža, te školu u kojoj nastavnici rade.

Utvrđeno je da između odgovora nastavnika s obzirom na pol postoji statistički značajna razlika o nekim pokazateljima pedagoškog takta nastavnika. U tvrdnjama vezanim za ,...veština upravljanja učenjem na času“ utvrđeno je da nastavnici (m) iskazuju veći stepen samopouzdanja od nastavnica (̌̌), dok u nekim tvrdnjama kroz koje se može iskazati prisnost i toplina - nastavnice (̌̌) to više iskazuju. Isto tako, utvrđeno je da između odgovora nastavnika s obzirom na stručnu spremu postoji statistički značajna razlika o nekim pokazateljima pedagoškog takta nastavnika, našta je delovala priroda nastavnog predmeta i stručne osposobljenosti nastavnika. U analizi je dalje utvrđeno da između odgovora nastavnika s obzirom na godine radnog staža postoji statistički značajna razlika o nekim pokazateljima pedagoškog takta nastavnika, kao i s obzirom na školu u kojoj rade.

$\mathrm{Na}$ osnovu ovako dobijenih rezultata istraživanja potvrđena je naša hipoteza, koja je glasila: „Pedagoški takt nastavnika varira u zavisnosti od stručne spreme, godina radnog staža i pola nastavnika“. 


\section{Zaključak}

Polazna hipoteza u ovom radu koja je glasila: Pedagoški takt nastavnika varira u zavisnosti od stručne spreme, godina radnog staža i pola nastavnika je potvrđena. Da bismo testirali ovako postavljenu hipotezu, ispitivali smo mišljenja direktora i stručnih saradnika, a nakon toga i stavove nastavnika.

U procesu realizacije empirijskog istraživanja, uz primenu odabrane metodologije istraživanja (metoda, tehnika $\mathrm{i}$ instrumenata), kao i različitim statističkim postupcima pomoću kojih smo testirali polazne pothipoteze, potvrdili smo našu generalnu hipotezu da je rad savremene osnovne škole u Republici Srbiji zasnovan na saznanjima pedagoške nauke.

\section{Literatura}

Danilović, M. (2011). Novi vaspitno-obrazovni ciljevi i uloge nastavnika koji uslovljavaju i određuju metode, oblike i sadržaje njihove edukacije za budućnost. Zbornik radova 3. Međunarodni naučno-stručni skup, Edukacija nastavnika za budućnost. Zenica: Pedagoški fakultet u Zenici.

Ilić, M., Nikolić, R. i Jovanović, B. (2012). Školska pedagogija. Banja Luka: Filozofski fakultet.

Kačapor, S.,Vilotijevic, N. (2005) Školska i porodična pedagogija. Učiteljski fakultet u Beogradu, Filozofski fakultet u Kosovskoj Mitrovici.

Kulić, R. (1996). Sadržaj rada i obrazovanje. Beograd: Institut za pedagoška istraživanja.

Kulić, R., Despotović, M. (2010).Uvod u andragogiju. Beograd: Svet knjige.

Pravilnik o standardima kvaliteta rada ustanove „Službeni glasnik RS“, broj 7/2011 i 68/2012).

Strategija razvoja obrazovanja u Srbiji do 2020. godine, (,Službeni glasnik RS“, br. 107/2012).

Zakon o osnovnoj školi (,Službeni glasnik RS“, br. 50/92, 53/93, 67/93, 48/94 i 66/94).

Korišćeni internet izvori

http://www.unijasprs.org.rs

http://europa/eu/int/

www.eurydice.int 


\title{
TEACHER - MAIN FACTOR OF INTRODUCING OUR SCHOOLS IN EDUCATIONAL MILES OF MODERN EUROPE AND THE WORLD
}

\author{
Ilinka Mušikić Popović \\ University of Priština, Faculty of Philosophy in Kosovska Mitrovica, \\ Department of Pedagogy
}

\begin{abstract}
The paper discusses the role of the teacher as the most important carrier pedagogical school work, its organization, current teaching process, educational influence on students and presentation to the school social environment. The teacher is portrayed as the most important factor of any changes in the school, and thus as the most important factor over which our school can be modernized, to accept the challenges of modern Europe and the world, this factor to our school finally included within modern schools with schools of equal developed countries Europe and the world .

The paper clearly separated into two parts: (1) Theoretically, discussing the most important issues of contemporary school, as one that is affirmed as successful the organization, as well as those that give rise to reasoned criticism. A special place is given to the teacher, his character, his function, place the role of the pedagogical cycle - the holder of the most important functions of the school and column factor to its success and / or failure; (2) Empirical part to give a copy of a broader research that explicitly refers to only one pedagogical phenomenon - pedagogical tact teachers.
\end{abstract}

Keywords: pedagogy, upbringing, education, teacher, schools, school organizations.

\section{Citiranje članka:}

Mušikić Popović, I. (2018). Nastavnik - glavni faktor uvođenja naše škole u pedagoški milje savremene evrope i sveta. Godišnjak za pedagogiju, 3(1), 19-28. 